\title{
Vulnerability and Resilience of the Mining Communities. The Case of Bukovina Region, Romania
}

\author{
Viorel CHIRIȚĂ'1, Daniela MATEI ${ }^{*}$ \\ *Corresponding author \\ 1 "Ștefan cel Mare" University of Suceava, Faculty of History and Geography, Department of Geography, Suceava, ROMANIA \\ 2 Romanian Academy, Institute for Economic and Social Research "Gh. Zane", Iași, ROMANIA \\ E-mail:vnchirita@gmail.com, daniela_matei2004@yahoo.com \\ DOI: 10.24193/JSSP.2019.2.08 \\ https://doi.org/10.24193/JSSP.2019.2.08
}

K e y w o r d s: vulnerability, resilience, mining communities, mountainous rural areas, development

\begin{abstract}
A B S T RA C T
The decision to cease mining activities in Bukovina between 1997 and 2007 was a major challenge for the population of the whole region. It made the local and regional communities and public authorities to mobilize and manage other available economic resources, namely forest, wood, water, tourist attractions or agricultural land. The economic vulnerability of communities has increased both due to the loss of jobs by a large number of people and the lack of taxes and royalties that the mining community owed to communities. This lack of source of community investment has become unavailable together with the financial support provided by a series of services related to the mining site, also used by the community: water supply, social services, supply or transport infrastructure. This study is the result of a survey based on questionnaires and interviews carried out in three mountainous communities of Bukovina, where the cessation of mining activity has led to an escalation of social and economic vulnerabilities. Authors investigated the source of origin of post-mining investments to obtain information about the resilience level acquired by the communities. The final analysis corroborated the results obtained from questionnaires with data from national statistics and local administration. The research results highlight the need to approach sustainable development by two types of concurrent processes: the co-participation of community members to improve living conditions, with emphasis on their own decisions, and secondly, the adoption of policies by local governments to encourage initiative, self-support and mutual help to make them more effective.
\end{abstract}

\section{INTRODUCTION}

Since 1987 when the term sustainable development first appeared, mountain regions have been considered central elements of the environmental and sustainable development policies. Their problems and difficulties in adapting to the dynamics of the world economy and climate change require constant attention. The reason for this concern is mostly economic and caused by the resources of thesemountainous areas. Regardless of which resources are targeted, their capitalization (or cessation of capitalization, in the case of mining resources) affects both the biodiversity and the well-being and dynamics of local community development. Obviously, the prospect of economic development is very important at the regional and local level, but for the local communities that are directly dependent on the resources offered by the mountains, it first, triggers vulnerability. Other causes of vulnerability are generated by the proximity of forestland to permanent settlements, forest ownership status, climate conditions, distinctive features of morphoclimatic systems, limited accessibility due to morphometry, lack 
of access to commercial markets, education and medical services, dependence on one economic factor (resource) or inadequate government interventions. In addition, there is the fragility of the mountain ecosystem due to some factors and conditions specific to the territorial system - altitude or hydrological and meteorological phenomena, relations between communities and mountainous areas, each with a role in the management of the ecosystem's valuable resources (water, timber, forest fruits, medicinal plants, energy, recreational services etc.).

The vulnerability of the territorial system is associated with the ability of a community to anticipate and, mostly, to resist stressful environmental transformations (Bălteanu et al., 2003; Wisner et al., 2004). According to the Vulnerability Working Group of the United Nations Environment Program, vulnerability is the degree of human and community resistance to risks and hazards; moreover, vulnerability can express the degree of community exposure to shocks and crises, but also the adaptation to the social, economic and human shocks they produce (Bălteanu and Costache, 2006.)

Community governance is linked to its degree of vulnerability in terms of crisis management capacity. By the sustainable use of existing economic, social, political or infrastructure resources, local government can reduce damage caused by natural, technological or mixed hazards. Community insecurity, driven by the increase in vulnerability after impact, must be analyzed in the light of the complex interactions that exist within the territorial system. The external side of the territorial system's vulnerability corresponds to the exposure of the population to environmental risks (Chambers, 1989; Spitz and Trudinger, 2019).

Most of the vulnerability studies analyzed this external aspect, neglecting the internal dimension. A correlation of natural phenomena with the socioeconomic structures affected by a major event such as mine closure is more appropriate to open socioecological territorial systems, such as the rural mountain communities in the Eastern Carpathians. Most of the studies that analyzed the mining areas in Romania are recent and they cover a wide range of problems of the mining communities, regardless of the geographical area where they are located (Oltenia, the Apuseni Mountains, Maramureș or Bukovina). We must mention the concerns for the evaluation of the vulnerability of the mining settlements (Constantin et al., 2015; Alexandrescu, 2011), of the socio-economic effects of the mine closure (Andrioni, 2017, Mitrică et al., 2017) or of future development models (Danciu and Radoslav, 2015; Preotesi, 2014).

Generally speaking, the social and economic dimension of the vulnerability of settlements in mining areas includes the types of impact produced in the territorial system. From access to natural, educational and informational resources, population structure, distribution and dispersion of households, quality of life, to the state of infrastructure, quality of the built infrastructure and resilience of the respective communities. In the case of mountain communities, the most common reasons are the exploitation of the resources they have. We are talking about a kind of vulnerability created by the effort to comply with the sustainable development policy and the sensitive balance between resource exploitation and the value of ecosystem services. Numerous situations of fragile community balance are particularly found in regions where exploitation of some mining-related activities has been conducted for a long time, and has had medium and long-term effects, such as the destruction of the substrate, tailings dumps and settling ponds. The return to a new balance after such circumstances requires special time and policies adapted to the type of environment affected: natural, economic or social. The response of the entire mountain area to all these challenges depends on the ability of the natural environment and communities to cope with unforeseen situations (defined by the term 'resilience') and the increase in resilience of the socio-ecological systems of which it is part.

The resilience analysis presented in the paper focuses on the solutions that the communities have enforced to deal with the vulnerabilities generated by a complicated socio-economic and political context, determined by the end of ores exploitation in Bukovina (Suceava County). Our research provides empirical evidence on the importance of leadership in the community along with community initiative, participation and self-sustainability as essential elements of resilience.

\section{THEORY AND METHODOLOGY}

The exploitation of mineral resources causes different degrees of vulnerability in mountainous areas, both during and after completing the process. For the mining communities the end of exploitation activities made the difference between prosperity and subsistence because of the relationship of interdependence established between the mine and the community on multiple plans (employment, services, infrastructure, the environment, taxes, and fees). The ability of the community to cope with the (total) disappearance of the main employer in the region is defined as resilience (Leykin et al., 2013) and reflects the ability to maintain, renew or reorganize the functions of the entire social and economic system (Varghese et al., 2006). From this perspective, resilience is a measure of diminishing the vulnerability of a community, materialized by its efforts to maintain behaviour, rules and norms that promote social benefits for the community as a whole (Smit and Wandel, 2006). This effort implies that both residents 
and local government should make individual and collective decisions to adapt the community to major impact events (Walker et al., 2004, Spitz and Trudinger, 2019). Regardless of the regeneration mechanisms of the community, the process itself is marked by a series of factors that influence the pace of development, of which the vulnerability of the system has the most important role (Maguire and Cartwright, 2008). In a series of works it has been argued that, due to the radical transformations that sometimes occur in the development policy, individuals and communities need to be prepared in advance through appropriate governmental programs, so that, at the time of the event, they should be able to have the initiative and the courage to identify new opportunities (Spaargaren and van Vliet, 2000, Heyns and Mostert, 2018). In other words, their behaviour must indicate the acceptance of change in order to trigger the process of adaptation or resilience (Nye and Burgess, 2008, Adger et al., 2009).

This paper integrates the results of a research project that aimed to quantify the individual and community resilience in three villages of Bukovina region (Romania), as former mining areas (see figure 1). Developed between 2017 and 2018, the project involved, among other things, the analysis on the population's perspective on the solutions they were provided to deal with the shock of the cessation of the mining activities (DIPACULT, 2017). The studies consulted for research highlighted the diversity of strategies adopted by communities and individuals in response to various shocks (Yadav and Jamal, 2018, Maier et al., 2014, Kinsey et al., 1998), such as mine closure in Romania (Radu, 2018, Chiriţă and Schmitz, 2017, Filimon et al., 2011). Given the characteristics of the three communities, we were particularly interested in the importance given to the diversification of the means of living through internal and external migration (Ellis, 1998; Béné, 2009, Radu, 2018).

The quantification of resilience of the selected communities, affected by long-term mining, was achieved through qualitative descriptive research, by face-to-face questioning. The target group consisted of people working in the mining sector (or members of their families) in three communities in Bucovina (Şaru Dornei - 106 valid questionnaires, Fundu Moldovei 106 questionnaires, Ostra - 61 questionnaires). In order to identify the resilience resources of the communities of these three localities, we employed two indicators assessed through interviews: the solutions adopted by community members to overcome personal and family problems resulting from the cessation of mining activities and the sources of community investment funding in the post-mining period. The latter indicator provided information on the level of resilience acquired by communities. The final analysis corroborated the results obtained from questionnaires with data from the national statistics and that of the communities under study. Questionnaires with a response rate of more than 90\% were considered valid.

\section{RESULTS AND DISCUSSION}

The resilience analysis that followed the survey was performed in two steps. First, we identified the types of vulnerability that affected the mountain communities in Şaru Dornei, Fundu Moldovei and Ostra from Bukovina region (Eastern Carpathians, Romania, Figure 1).

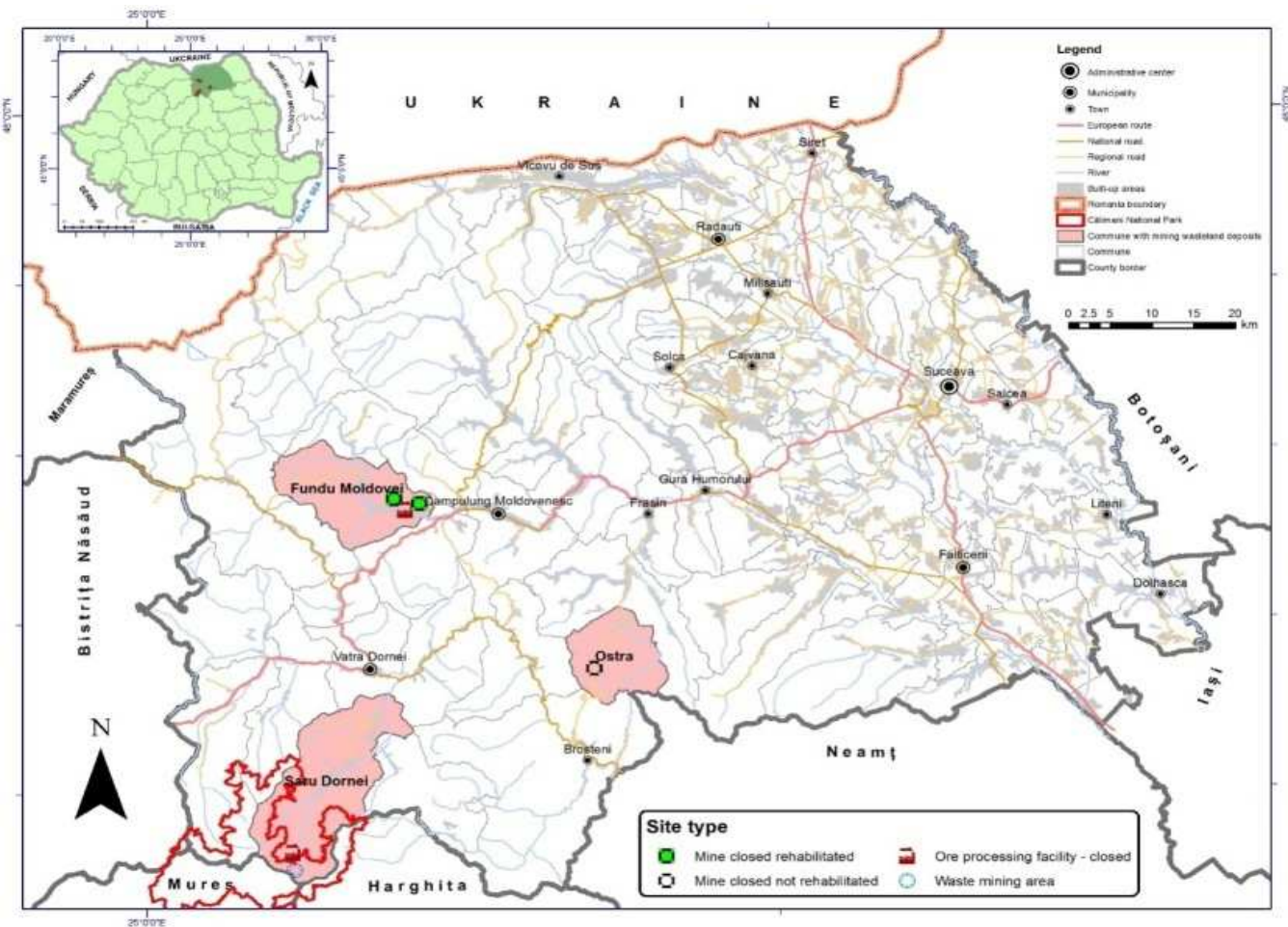

Fig. 1. Complex vulnerability sources in the analyzed communities: mining areas. 


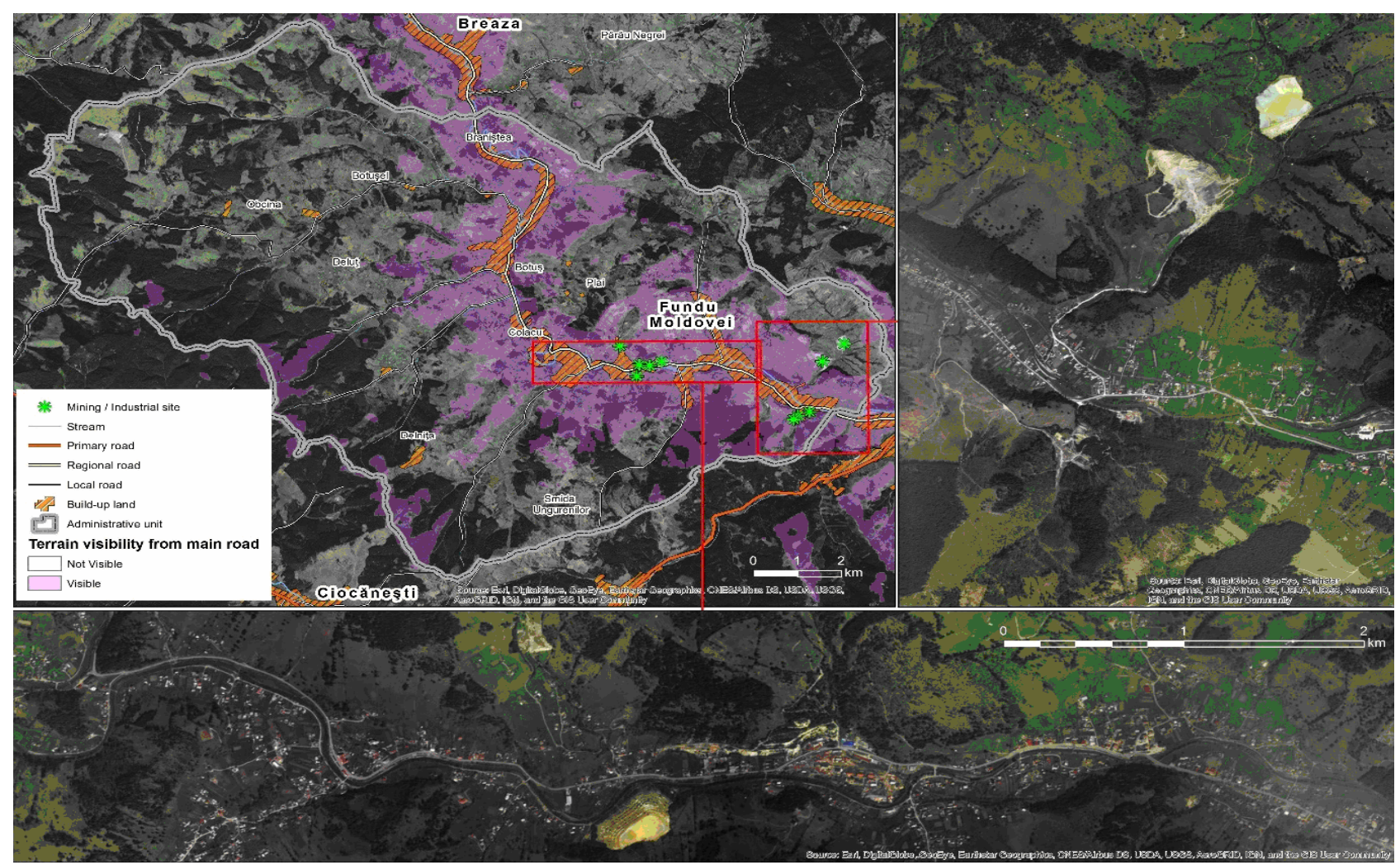

Fig. 2. The level of visibility of the geographical landscape with abandoned mining sites from the access roads in Fundu Moldovei (digital cartography by Ionuț Cristea, 2017).

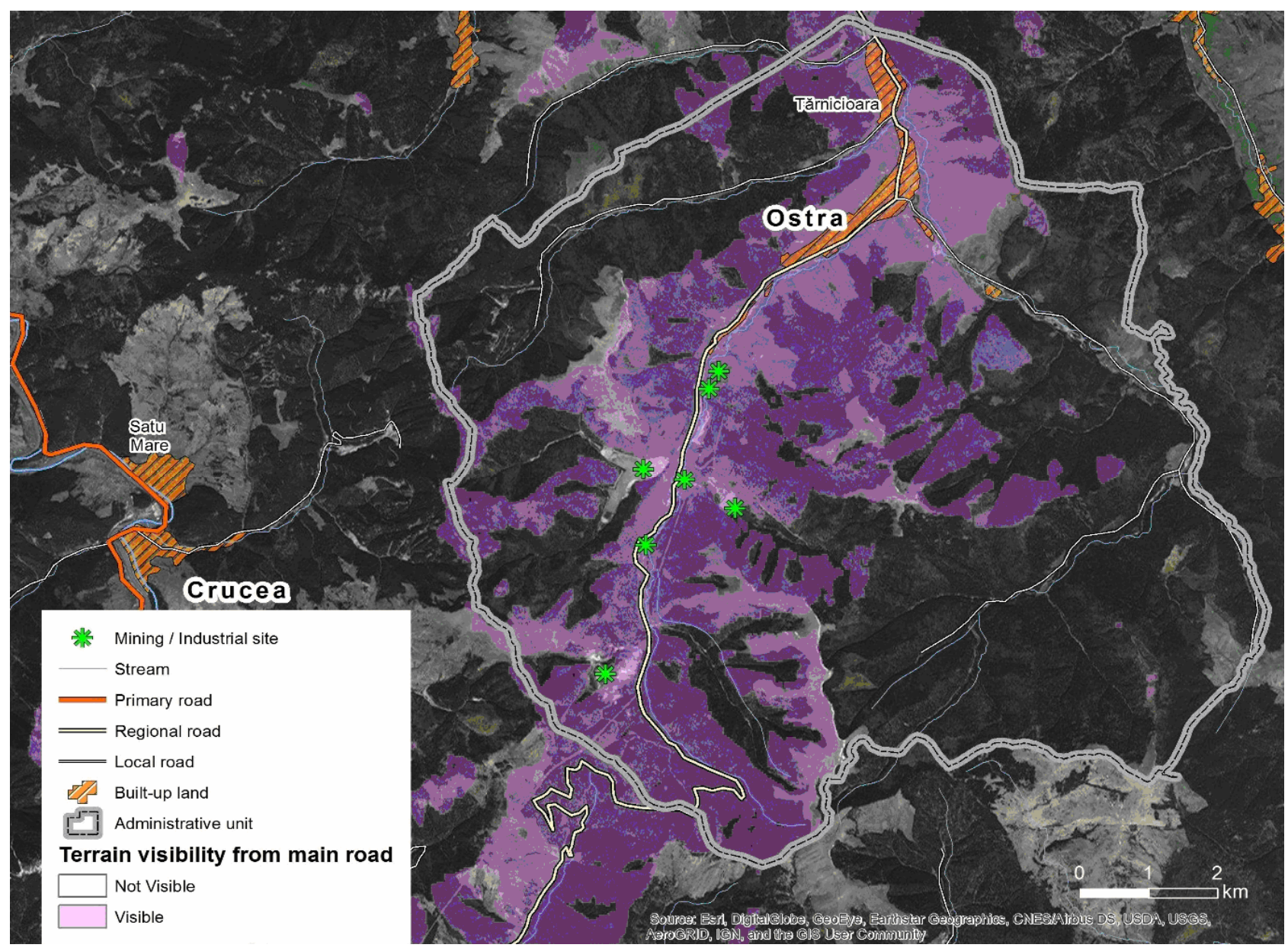

Fig. 3. The level of visibility of the geographical landscape with abandoned mining sites from the access roads in Ostra (digital cartography by Ionuţ Cristea, 2017). 


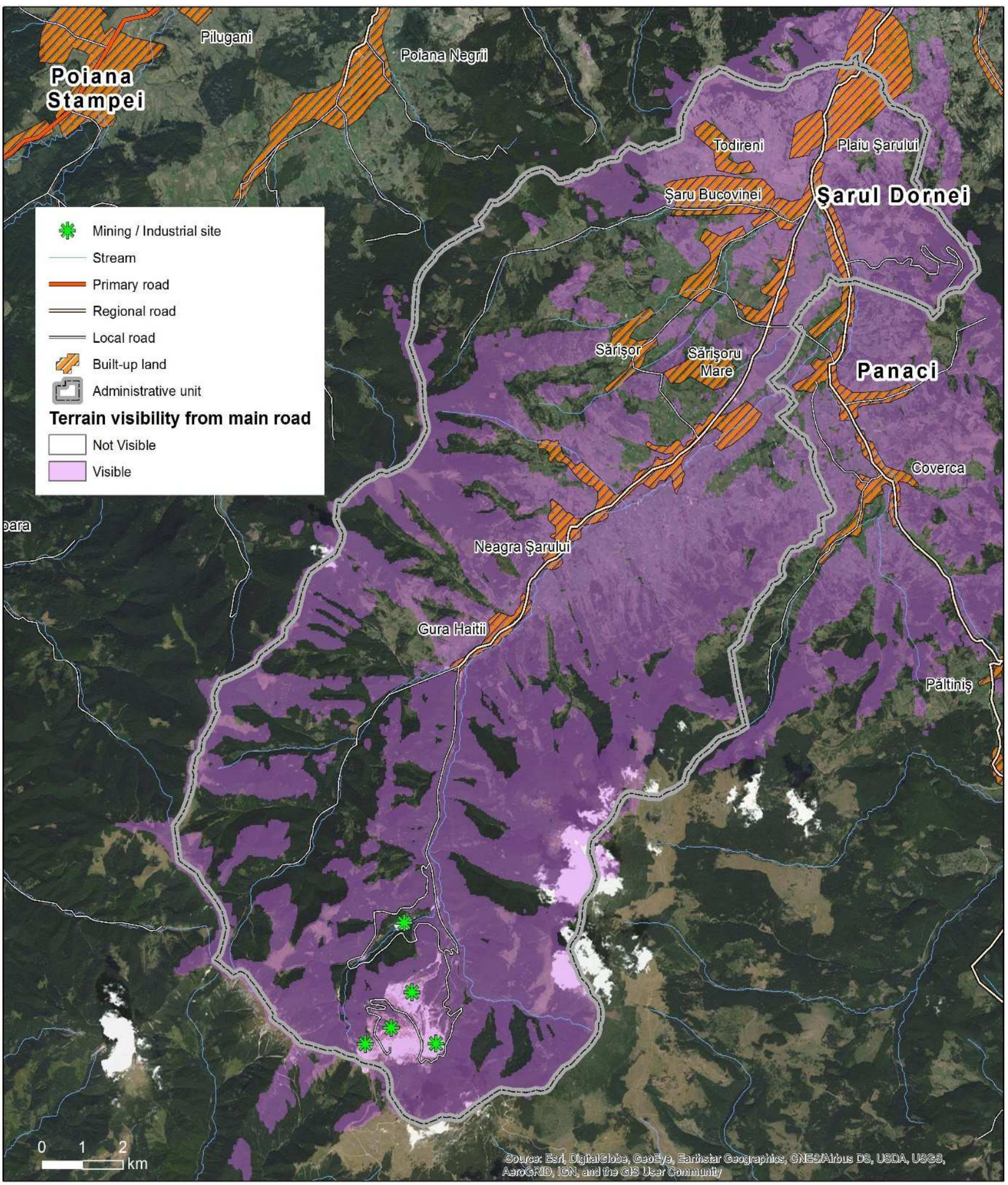

Fig. 4. The level of visibility of the geographical landscape with abandoned mining sites from the access roads in Şaru Dornei (digital cartography by Ionuț Cristea, 2017).

The closure of the mining operations in these three settlements and their proximity was completed in 2007, and the main identified vulnerabilities were territorial, social, economic and environmental. The second stage of the study aimed at identifying the resilience resources available to residents and local administrations to reduce the above-mentioned vulnerabilities.

\subsection{Sources of vulnerability}

Mining exploitations caused different types of vulnerabilities for the people inhabiting the selected areas, them being exposed to the risk of natural, social or economic events (Wisner et al., 2004). This is why the sources of vulnerability will not be approached separately, but directly related to the area they had 
effects on. First of all, the functional spaces related to the mining operations are currently sources of geographic, natural, technological or mixed risks and hazards, that pose an even greater danger when located either in the vicinity of communities such as - Ostra and Şaru Dornei - or in urban areas - Fundu Moldovei. The greatest potential risk is given by tailings dumps and quarries, which radically alter the geographic landscape and increase its vulnerability.

The high visibility of the mining wasteland landscape - from the access roads -, allows us to understand the complex relations between the different types of location and their neighbourhood (Figures 2, 3 and 4). By analysing the environmental issues by the level of visibility of the mining landscape could be useful for better understanding the phenomena. For example, in the case of Fundu Moldovei (Fig. 2), the greatest danger is generated by the pond of Dealu Negru, located at about $10 \mathrm{~m}$ from Moldova river and 100 meters from the first household. In the same area, the remnants of the copper ore plant, mines, and smaller dumps are located right near the county road.

In the case of Ostra, a few hundred meters from the built up area of the village, there are four settling ponds (among them Lake Tărnicioara, one of the largest in Europe), also visible from the road (Fig. 3). Due to the morphoclimatic systems in which the site is located, specific to a mountainous forest area and rich hydrographical network, there is a quick transfer from upstream to downstream areas. The physical-chemical components from the old mining sites represent a constant threat and risk for the downstream communities of Ostra, Fundu Moldovei, Gura Haitii, Neagra Șarului.

Another perspective on vulnerability takes into account those community features that define a certain imbalance that the mining cessation caused. We considered a set of socio-economic factors (poverty, inequality, housing quality or access to services) that have undergone changes following the lack of jobs and the reaction of adapting communities to this interruption in the continuity of development. We are talking, first, about a social vulnerability of a large number of people generated by the switch from a substantial income (above the average wage in Romania at that time (Radu, 2018), to the status of unemployed or person looking for a similarly paid job. This conjuncture created two other types of vulnerability: some of the laid off people suddenly faced a subsistence income and reconsidered traditional agricultural or forestry activities, and some others left the country in search of a new job.

Migration for work is an extreme manifestation of social and economic vulnerability. Frequently encountered as a strategy in resourcedependent communities, migration contributes to maintaining a lifestyle and adaptability at family level through remittances that offer opportunities for diversification. Income from remittances tends to be invested in human and physical capital and less in immediate consumption. Regardless of the destination, the massive migration of the working-age population is an indicator of the weakening of social resilienceand an extreme manifestation of vulnerability.

\subsection{Resilience resources}

Mining activities are important economic engines for local communities and their disappearance creates difficulties for both the community as a whole and the individuals, by varying incomes and significant changes in the living standards of a community.

\subsubsection{Solutions adopted by community members in the post-mining period}

This indicator refers to the level of personal involvement of former miners and their family members in finding individual solutions to support a decent living standard after mine closure.

Five resilience variants of the individuals of the former mining communities concerning the postmining period (2004-2017) were explored: use of personal savings, orientation towards entrepreneurial activities, obtaining a job in another region of the country, departure abroad looking for a job or a bank loan to successfully overcome difficult times.

It should be noted that irrespective of the type of response recorded when completing the questionnaires, they were not unilateral except in isolated cases. Respectively, a person used personal savings to focus on other activities offered by the resources of the area or went abroad looking for a job. Bank loans were also used to start an agricultural, tourism or agricultural/ forestry processing business, but especially to generate a subsistence financial stock abroad until a job was found. Although bank loans were chosen in only $13 \%$ of the people interviewed in Ostra, and by $7 \%$ of the people in Şaru Dornei, they were a real solution especially for the members of the families of miners who went to work abroad. It is very true that, through measures taken by the government to mitigate the economic shock amongst the unemployed former miners, part of them received compensations to be invested in activities that could become alternative income sources. Although most beneficiaries of such amounts invested in goods and less in incomegenerating activities, the years 2005 and 2008 brought an explosion of investments in rural areas previously considered disadvantaged. It was either a territorially planned measure (plots given by the local administration to entrepreneurs - Fundu Moldovei) or a spontaneous growth of investments in the development of tourist facilities or in small units of 
dairy production and processing (Fundu MoldoveiDeluţ, Şaru Dornei and Panaci). Most of the investments concerned wood cutting and primary processing from the mountain regions in the proximity of the three villages. Measures taken by the government to mitigate the shock caused by mine closures solved the problems, according to the survey, for only $55 \%$ of the people interviewed in Fundu Moldovei, 25\% of those in Ostra and $41 \%$ of the families in Şaru Dornei.

Table 1. Solutions adopted by community members to overcome the difficulties generated by mine closure (source: DIPACULT (2017), Project database).

\begin{tabular}{|c|c|c|c|c|c|c|}
\hline \multirow[t]{2}{*}{ Strategy } & \multicolumn{2}{|c|}{$\begin{array}{c}\text { Fundu Moldovei } \\
\text { (106 valid } \\
\text { questionnaires) }\end{array}$} & \multicolumn{2}{|c|}{$\begin{array}{c}\text { Ostra } \\
\text { (61 valid } \\
\text { questionnaires) }\end{array}$} & \multicolumn{2}{|c|}{$\begin{array}{c}\text { Şaru Dornei } \\
\text { (106 valid } \\
\text { questionnaires) }\end{array}$} \\
\hline & $\begin{array}{c}\text { No. of } \\
\text { answers }\end{array}$ & $\%$ & $\begin{array}{c}\text { No. of } \\
\text { answers }\end{array}$ & $\%$ & $\begin{array}{c}\text { No. of } \\
\text { answers }\end{array}$ & $\%$ \\
\hline Use of personal savings & 13 & 12 & 9 & 15 & 19 & 18 \\
\hline $\begin{array}{l}\text { Orientation towards other activities (wood } \\
\text { processing, agriculture, tourism etc.) }\end{array}$ & 58 & 55 & 15 & 25 & 43 & 41 \\
\hline Migration abroad for a job & 35 & 33 & 32 & 52 & 25 & 24 \\
\hline Bank loans & - & - & 8 & 13 & 7 & 7 \\
\hline Finding a job in the country & 28 & 26 & 16 & 26 & 35 & 33 \\
\hline
\end{tabular}

Since 2004, an important number of young miners, as well as a significant number of labour force provided by other members of the miners' families, began to emigrate, which has turned into a constant trend since 2007. This has generated another dimension of social vulnerability, resulting in an increase in isolation, population aging and increased feminization in the mountainous areas.

Among the three localities, the highest values of emigration caused by mine closure are registered in Ostra $(52 \%$ of the answers to the questionnaires indicated emigration as the main survival solution) as a result of the fact that the locality was/is dependent on a single resource (ore) and most of the active population was occupied with mining. From the responses recorded in the other two villages, labour migration (whether internal or external) was a general workforce strategy of the population formerly employed in the mining industry.

The statistical data, together with the answers to the questionnaires, showed very high percentage of the population working abroad, for all three communities analyzed: Fundu Moldovei - 591 persons (30\% of the active population), Ostra - 370 persons (25.3\% of the active population), Şaru Dornei - 232 persons (15.9\% of the active population).Even if the questionnaire showed that the internal labour migration was an important option for all three communities, national statistics recorded relatively constant values of this indicator, of $3 \%$ at Fundu Moldovei and Saru Dornei, from 2000 to 2017, and of 1.5\% at Ostra (INS, 2019), perhaps reflecting a resilience alternative that was used at a certain time. Our conclusion is that labour migration reflects a steady attitude in resource-dependent communities, which highlights an important social and economic vulnerability (Matei, 2017).

\subsubsection{Investment funding sources for the communities}

The radical elimination of mining industry has led to a mobilization of efforts of the local communities and administrations to shift their attention to other resources, with varying degrees of vulnerability: forest, wood, water, tourism or agriculture (Smith A., 2000). We analysed the process of community members' participation in their efforts to improve living conditions, with an emphasis on the level of community involvement reflected in individual actions as well as those of local administrations.

The level of community involvement resulted from the number and diversity of known investment projects that were made in each of the three communities. Regardless of whether they are projects supported by community budgets or by external funding (governmental or European), the applied questionnaires measured the level of community involvement, both at the individual level and at the level of the local public administration, by the perception of the inhabitants about the investments made in the community. The respondents were invited to designate, to their knowledge, the sources of investment funding of the same period that we have reported for detailing the previous indicator (2004-2017), and we synthesized the results of the questionnaire in Table 2.

In all three communities we found wellinformed citizens on the destination of local budget investment funds. Respondents were able to accurately detail the investments made from the local administration's budget. Supplementing the information in the questionnaire with our own inquiry at the local authorities for the period 2004-2017, we found that 30 projects were implemented in the case of Fundu Moldovei (social, infrastructure or 
environmental protection), seven projects in Ostra and nine projects in Şaru Dornei. In addition, there are other projects carried out through local administrations but with funding from external sources (governmental, European, county or regional): 17 projects in Fundu Moldovei and 12 in Ostra and Şaru Dornei. Given that some of them needed bank loans to be completed, in addition to the contribution from the local public authorities, it is a conscious effort made by local administrations to increase the quality of life in communities and create conditions for investment, given that public authorities elected by the citizens have no power to independently determine taxes and fees. Therefore, they cannot effectively design and support policies that promote the interests of their own communities. On the other hand, the financial resources transferred from the state budget to the local budgets reflect the relations of the "political family" existing between the local authorities and the governing party or coalition. Given the low degree of financial autonomy of local authorities, this type of relationship is often of significant importance. A quick view at the structure of local administration's revenue sources reveals a small degree of decentralization. What is important is that these projects, together with those supported through the European funds, contributed greatly to the resilience of these communities.

Table 2. Sources of investment funding for the community (source: DIPACULT 2017, Project database).

\begin{tabular}{|c|c|c|c|}
\hline \multirow[t]{2}{*}{ Funding source } & $\begin{array}{c}\text { Fundu Moldovei } \\
\text { (106 valid } \\
\text { questionnaires) } \\
\end{array}$ & $\begin{array}{c}\text { Ostra } \\
\text { (61 valid } \\
\text { questionnaires) } \\
\end{array}$ & $\begin{array}{c}\text { Șaru Dornei } \\
\text { (106 valid } \\
\text { questionnaires) } \\
\end{array}$ \\
\hline & No. of answers & No. of answers & No. of answers \\
\hline Local budget & 106 & 61 & 106 \\
\hline Government and county grants & 49 & 23 & 37 \\
\hline External sources (international programs) & 25 & 18 & 50 \\
\hline Private investments & 21 & 5 & 24 \\
\hline Bank loans & 6 & 3 & 12 \\
\hline
\end{tabular}

The role of local authorities in small communities can be very strong, beyond informal aspects (everyone knows everyone), especially when it comes to building the collaboration between school and the local labour market. The mayors and the local council in the analyzed communities are much involved in attracting investments, as we noted in our project field trips and interviews with residents. However, any private investment that is significant to the community cannot bypass local authorities, and its success depends largely on the willingness to work with the local authorities.

Therefore, good management of the resources available to the community, attracting new resources, but above all good governance, depends largely on the interconnection of sustainable development with community development. In all three analyzed communities, the efforts of population merge those of the government authorities and the private sector in order to increase the quality of life. We consider that there are, in fact, two types of simultaneous processes: the participation of people in efforts to improve their living conditions, with as much emphasis on involvement in the community, and the adoption of policies that encourage initiative, self-support and mutual help to make them more effective.

\section{CONCLUSIONS}

This research is motivated by the increased attention to concepts such as vulnerability and resilience in the international and national literature.
The empirical analysis carried out on the communities inhabiting Fundu Moldovei, Ostra and Șaru Dornei settlements in the Eastern Carpathian mountain region was intended to contribute to the understanding of the economic and social resilience mechanisms of the former mining communities, using measurable indicators.

1). In the analyzed villages during the postmining period, activities were oriented, in different shares, towards a mix of agriculture, forestry, tourism and small processing activities, partly supported by shipments of funds from family members working abroad.

2). Moving to work abroad remains an option for the vast majority of workers. However, after more than 10 years since the mine closure, in the case of all three communities, the perception of those who remained at home shows nostalgia for the period of economic and social stability given by the long-lasting functioning of mines. What is also interesting is that people believe that the environmental disruption and health problems caused by mine operation were an inherent and common component of the mining profession, which did not have a major impact on the quality of their lives. This disconnection between the actual impact of mining-related vulnerabilities and the general perception of the inhabitants, has now become an attribute of local resilience, in the sense of a deliberate transformation of vulnerabilities (such as the mining wastelands of the Călimani quarry, for example) into major tourist attractions, or the return to the traditional pre-mining occupations. 
3). An important factor of resilience, for all three communities analyzed, is the tradition of local polarization. Here, the investments made to improve the accessibility of intra and trans-Carpathian roads played a very important role. Neagra Şarului has always polarized the Eastern compartment of Dornelor Depression, while Ostra and Fundu Moldovei have created polarizations linked to the axis of North transCarpathian communication.

4). Communities have reached different degrees of resilience during the analyzed period, mainly due to: the involvement of local administrations and the population in the local entrepreneurship and diversification of the business structure.

5). Results also suggest that elements of good governance at the community level, such as social cohesion, leadership or community actions, represent three components of resilience that act synergistically to reduce the different types of vulnerability of the areas studied.

Following the analysis of the three mining communities, we conclude that, although the mining activity ceased to exist at relatively the same time, each of them is in a different phase of economic and social recovery. Each of them has a different development pace, rooted in the available resources and in assuming the search for a new economic destiny.

\section{REFERENCES}

Adger W. N., Dessai S., Goulden M. (2009), Are there social limits to adaptation to climate change?, Climatic Change, 93(3-4), 335-354, DOI: https://doi. org/10.1007/s10584-008-9520-z

Alexandrescu F. (2011), Gold and Displacement in Eastern Europe: Risks and Uncertainty at Roşia Montană. Romanian Journal of Sociological Studies, (12), 78-107. URL: https://econpapers.repec.org/article/ lumrev19g/v_3a1-2_3ay_3a2011_3ai_3a_3ap_3a78107.htm

Andrioni F. (2017), Social-economic influences of mining syncopes in the Jiu Valley over the members of the community. Annals of the University of Petrosani Mining Engineering, 18, 178-189.

Bălteanu D., Costache A., Tanislav D. (2003), Modificările mediului și vulnerabilitatea așezărilor umane. Exemplificări din Subcarpații și Piemontul Getic, (Article in Romanian), Analele Universităţii "Valahia" Târgovişte, Seria Geografie, 3, 25-28. URL: https://fsu.valahia.ro/images/avutgs/1/2003/2003030 129.pdf

Bălteanu D., Costache A. (2006), Conceptul de vulnerabilitate. Aplicații în Geografie, Revista Geografică, 12, 5-12. (Article in Romanian).

Béné C. (2009), Are Fishers Poor or Vulnerable? Assessing Economic Vulnerability in Small-Scale Fishing Communities, The Journal of Development
Studies, 45(6), 911-933. DOI: https://doi.org/10.1080/ 00220380902807395

Chambers R. (1989), Editorial Introduction: Vulnerability, Coping and Policy. IDS Bulletin, 20, 1-7., DOI: http://dx.doi.org/10.1111/j.1759-5436.1989. mp20 002001.x

Chiriță V., Smitz S. (Eds.) (2017), Les Friches minieres: paysage culturel et enjeu de développement rural. Regards croisés entre la Bucovine et la Wallonie, Atelier des Presses, Liège. [Waste mining deposits: cultural landscape and rural development issue. Crossed views between Bucovina and Wallonia]. ISBN 978-2-930772-23-3. (Book in French)

Constantin V., Ştefănescu L., Kantor C. M. (2015), Vulnerability assessment methodology: A tool for policy makers in drafting a sustainable development strategy of rural mining settlements in the Apuseni Mountains, Romania. Environmental Science \& Policy, 52, 129-139. DOI: https://doi.org/10.1016/ j.envsci.2015.05.010

Danciu M. I., Radoslav R. (2015), Accessibility as an agent for the reorganization and the sustainable development of the former mining communities. Proceedings of the International Academic Conference on Management, Economics and Marketing in Vienna 2015, 273-289.

DIPACULT (2017), Project database: La dynamique des paysages culturels intégrant des aires avec des friches minières. Rétrospectives et perspectives géographiques en Bucovine (Roumanie) et en Wallonie (Belgique), [The dynamics of cultural landscapes integrating areas with waste mining deposits. Retrospectives and geographic perspectives in Bucovina (Romania) and Wallonia (Belgium)]. Accessed on 17.06.2019

Ellis F. (1998), Household strategies and rural livelihood diversification, The Journal of Development Studies, Scientific Journal, UK, 35(1), 1-38, 1998.

INS (2019), National Institute of Statistics, Romania, Accessed on 03.05.2019

Heyns A., Mostert H. (2018), Three Mining Charters and a Draft: How the politics and rhetoric of development in the South African mining sector are keeping communities in poverty, Law and Development Review, 11(2), 801-841. DOI: https://doi.org/10.1515/ ldr-2018-0038

Kinsey B., Burger K., Gunning J. W. (1998), Coping with drought in Zimbabwe: Survey evidence on responses of rural households to risk, World Development, 26(1), 89-110. DOI: https://doi.org/10. 1016/So305-750X(97)o0124-1

Leykin D., Mooli L., Odeya C., Avishay G., Limor A. D. (2013), Conjoint Community Resiliency Assessment Measure-28/10 Items (CCRAM28 and CCRAM10): A Self-Report Tool for Assessing Community Resilience, American Journal of Community Psychology 52 (3-4): 313-23. DOI: 10.1007/s10464-013-9596-O 
Maguire B., Cartwright S. (2008), Assessing a community's capacity to manage change: A resilience approach to social assessment, Bureau of Rural Sciences, Australian Government pp 1-33, URL: http://www.tba.co.nz/tba-eq/Resilience_approach.pdf, Accessed on 23.07.2019

Maier R. M., Díaz-Barriga F., Field J. A., Hopkins J., Klein B., Poulton M. M. (2014), Socially responsible mining: the relationship between mining and poverty, human health and the environment. Reviews on Environmental Health, 29(12), 83-89. DOI: https://doi.org/10.1515/reveh-20140022

Matei D. (2017), La rezilience économique et sociale post-activite miniere des communautes rurales de Fundu Moldovei, Ostra et Şaru Dornei. In Chiriță V., Smith S. (eds.) Les friches minières : paysage culturel et enjeu de développement rural. Regards croisés entre Bucovine et Wallonie, Atelier des Presses, Liège, 109137, ISBN 978-2-930772-23-3. (Book in French)

Mitrică B., Mocanu I., Dumitraşcu M., Grigorescu I. (2017), Socio-economic disparities in the development of the Romania's border areas, Social Indicators Research, 134(3), 899-916. DOI: https://doi.org/10.1007/s11205-016-1462-7

Nye M., Burgess J. (2008), Promoting durable change in household waste and energy use behaviour. A research report completed for the Department for Environment. In Food and Rural Affairs, School of Environmental Sciences, University of East Anglia, Norwich, UK, 30-31. URL: https://www.empowerment institute.net/index.php/docman-default-enabler/ behavior-change-research/96-promoting-durablechange-in-household-waste-and-energy-usebehavior/file, Accessed on 23.07.2019.

Preotesi M. (2014), Economic and social policies impacting on the social under-development-case study: mining restructuring in Valea Jiului. European Journal of Social Science Education and Research, 1(1), 208216. DOI: http://dx.doi.org/10.26417/ejser.v1i1.p208216
Radu B. (2018), Influence of social capital on community resilience in the case of emergency situations in Romania. Transylvanian Review of Administrative $\quad$ Sciences, 14(54), 73-89. DOI: http://dx.doi.org/10.24193/tras.54E.5

Smit B., Wandel J. (2006), Adaptation, adaptive capacity and vulnerability. Global Environmental Change, 16(3), 282-292, DOI: https://doi.org/10.1016/ j.gloenvcha.2006.03.008

Smith A. (2000), Employment Restructuring and Household Survival in 'Post-communist Transition': Rethinking Economic Practices in Eastern Europe, Environment and Planning A, 32(10), 1759-1780. DOI: https://doi.org/10.1068/a32101

Spaargaren G, Vliet B. V. (2000), Lifestyles, consumption and the environment: The ecological modernization of domestic consumption, Environmental Politics 9 (1), 50-76, DOI: https://doi.org/10.1080/o9 644010008414512

Spitz K., Trudinger J. (2019), Mining and the environment: from ore to metal, Second edition, Taylor Francis Group, London, ISBN 978-1-351-18366-6 (hbk). Varghese J., Krogman N. T., Beckley T. M., Nadeau S. (2006), Critical Analysis of the Relationship between Local Ownership and Community Resiliency, Rural sociology, 71(3), 505-527, DOI: https://doi.org/10.1526/003601106778070653

Yadav A. K., Jamal A. (2018), Impact of mining on human health in and around mines. Environmental Quality Management, 28(1), 83-87. DOI: https://doi.org/10.1002/tqem.21568

Wisner B., Blaikie P., Cannon T., Davis I. (2004), At risk: Natural hazards, people's vulnerability and disasters, Second edition, Routlege, Taylor and Francis Group, ISBN 0-415-25215-6 (hbk).

Walker B., Holling C. S., Carpenter S. R. (2004), Resilience, adaptability and transformability in socialecological systems, Ecology and Society,9(2), 1-9, URL: http://www.ecologyandsociety.org/vol9/iss2/art5/ 